Dhaka Univ. J. Biol. Sci. 21(2): 153-161, 2012 (July)

\title{
PTERIDOPHYTE FLORA OF RAMPAHAR AND SITAPAHAR RESERVE FORESTS UNDER RANGAMATI DISTRICT IN BANGLADESH
}

\author{
SARder NAsir UddiN* AND Md. Abul Hassan ${ }^{1}$ \\ Bangladesh National Herbarium, Chiriakhana Road, Mirpur-1, Dhaka-1216, Bangladesh \\ Key words: Pteridophyte flora, Reserve forest, Bangladesh
}

\begin{abstract}
A taxonomic survey was conducted to study pteridophyte flora of Rampahar and Sitapahar reserve forests under Rangamati district in Bangladesh. The survey was accompanied with collection of voucher specimens of the available pteridopyte species in the area and deposition at Bangladesh National Herbarium as reference material. The study found 41 pteridophyte species belonging to 26 genera under 13 families from the area. It constitutes 21 per cent of total fern flora of the country including one threatened species viz. Tectaria chattagramica (Clarke) Ching.
\end{abstract}

\section{Introduction}

Rampahar and Sitapahar forests reserve is one of the richest botanical areas in the Chittagong Hill Tracts region which was declared as the first reserve forest in 1875 from this area. The under explored forests of Rampahar and Sitapahar areas represents tropical rain forest mainly of evergreen type of vegetation. The forests are situated in Kaptai Upazila under Rangamati district. Administratively, the area belongs to Kaptai Forest Range under the management of Rangamati South Forest Division. The forests lie between $22^{\circ} 26^{\prime}$ and $22^{\circ} 38^{\prime}$ North and $92^{\circ} 08^{\prime}$ and $92^{\circ} 17^{\prime}$ East and occupy an area of 966 hectares of hilly land. The configuration of the ground is very irregularly rugged and consists of a series of ridges and valleys running more or less from north to south. The level of valley bottoms ranges from 30 to $90 \mathrm{~m}$ above the sea level and maximum elevation is about $500 \mathrm{~m}$. The hill soils are mainly yellowish-brown to reddish-brown loams and soil $\mathrm{pH}$ varies from $5.5-6.0^{(1)}$. Though the area is very rich in species diversity but a comprehensive floristic study of the area is still lacking. Presently this natural forest is under enourmous and persistent threats mainly due to different anthropogenic activities. As a result a number of economically important species/germplasm stocks have become endangered or threatened and perhaps extinct of a few. Therefore, it is essential to have an inventory of the forest wealth for conservation and sustainable management.

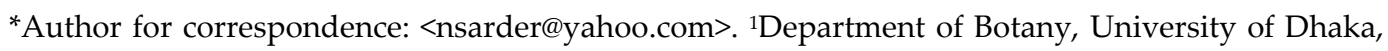
Dhaka-1000, Bangladesh. 
Pteridophytes are a group of plants which demand attention from anyone who studies nature in Bangladesh, but this group of plants have been excluded from most cases of floristic studies. Prain ${ }^{(2)}$ was the first person who enumerated 98 taxa of fern from the then East Bengal (present Bangladesh) but nomenclature of those taxa has been changed much in the recent year. After the independance of Bangladesh, only a very few studies on fern flora have been done by Pasha and Mallick(3), Pasha and Chakraborty(4), Pasha( ${ }^{(5)}$, Mirza and Rahman(6), Uddin and Pasha ${ }^{(7)}$, Uddin ${ }^{(8)}$. Recently, Siddiqui et al. ${ }^{(9)}$ compiled 195 species of pteridophyte from Bangladesh. Most of those works were based mainly on survey of available literatures and examination of deposited voucher specimens at different herbaria. In Bangladesh, ecosystem/forest/habitat wise fern flora study attempt has been done by few (Uddin and Pasha) ${ }^{(10,11)}$. Hence, the floristic study of Rampahar and Sitapahar reserve forests was carried out aiming to generate baseline information for any conservation and management activity of the areas.

\section{Materials and Methods}

The present work deals with the pteridophyte species of Rampahar and Sitapahar forest areas and is based on the specimens collected through extensive field search. The floristic inventory was done by using area maps and regular field visits, accompanied by the collection of fertile specimens of all available plant species. A total of 19 botanical exploration tours were made during 2001-2008 and over 200 field numbers of plants were collected. The areas were visited in every month and the forest was reached by walking on foot following the existing forest trails. The herbarium specimens were examined for comparison at the Bangladesh National Herbarium, Dhaka University Salar Khan Herbarium and Bangladesh Forest Research Institute Herbarium. Collected specimens were identified by consulting Beddome ${ }^{(12)}$, Clarke ${ }^{(13)}$, Holttum $^{(14,15)}$, Dixit ${ }^{(16)}$, Siddiqui et al.(9) and Smitinand and Larsen.(17,18) The specimens have been preserved at the Bangladesh National Herbarium (DACB). Fern families have been arranged according to the classification of Tagawa and Iwatsuki.(19) The genera and species under each family have been arranged alphabetically. Each species has been furnished with valid name, full original citation, well-known synonym (in few cases), habit, ecology and representative specimen.

\section{Results and Discussion}

The present floristic study has identified following fern species from Rampahar and Sitapahar reverve forest areas.

SELAGINELLACEAE Willkom (1861).

1. Selaginella repanda (Desv.) Spring in Gaudich., Voy Bonite Bot. 1: 329 (1846). Erect or decumbent herb. Commonly occurs in Rampahar and Sitapahar areas in shady and moist hill slopes. Representative specimen: Rangamati dist.: Sitapahar, Kaptai, 18 xii 2004, Sarder Nasir Uddin N-2601 (DACB). 
2. Selaginella tenera (Hook. et Grev.) Spring in Bull. Acad. Brux. 10: 232 (1843). Erect herb. Frequently occurs in both Sitapahar and Rampahar areas in shady and moist hill slopes. Representative specimens: Rangamati dist.: Sitapahar, Kaptai, 22 ix 2002, Sarder Nasir uddin N-1419 (DACB); Rampahar, Kaptai, 19 x 2003, Sarder Nasir Uddin N2122 (DACB).

3. Selaginella tenuifolia Spring, Mém. Acad. Roy. Sci. Bélg. 24 (2): 253 (1850). Erect herb. Commonly occurs in both Sitapahar and Rampahar areas in shady and moist hill slopes. Representative specimens: Rangamati dist.: Sitapahar, Kaptai, 26 ix 2002, Sarder Nasir Uddin N-1609 (DACB); Rampahar, Kaptai, 16 x 2003, Sarder Nasir Uddin N2051 (DACB).

EQUISETACEAE L. C. Richard $e x$ de Candolle (1805).

4. Equisetum debile Roxb. ex Vouch., Monog. Prel.: 387 (1821). Creeping-rhizomatous, tufted herb. Occasionally occurs in Rampahar area along the river banks, springs and in open grassy places. Representative specimen: Rangamati dist.: Rampahar, Kaptai, $01 \mathrm{x}$ 2002, Sarder Nasir Uddin N-1733 (DACB).

OPHIOGLOSSACEAE (R. Br.) Agardh (1882).

5. Helminthostachys zeylanica (L.) Hook., Gen. Fil.: t. 47b (1840). Rhizomatous herb. Frequently occurs in both Sitapahar and Rampahar areas in shady forest beds. Representative specimens: Rangamati dist.: Rampahar, Kaptai, 30 ix 2002, Sarder Nasir Uddin N-1703 (DACB); Sitapahar, Kaptai, 01 vi 2003, Sarder Nasir Uddin N-1999 (DACB).

MARATTIACEAE Berchtold et Presl (1820).

6. Angiopteris evecta (Forst) Hoffm., Comm. Soc. Reg. Sci. Gott. 12: 29, t. 5 (1796). Robust fern with erect stem. Commonly occurs in Rampahar area along shady chhara. Representative specimen: Rangamati dist.: Rampahar, Kaptai, 30 ix 2002, Sarder Nasir Uddin N-1670 (DACB).

POLYPODIACEAE Berchtold et Presl (1820).

7. Colysis pedunculata (Hook. et Grev.) Ching in Bull. Fan Mem. Inst. Biol. 4: 321 (1933). Woody rhizomatous, creeping or climbing herb. Rarely occurs in Rampahar area in shady and damp rocks. Representative specimen: Rangamati dist.: Rampahar, Kaptai, 30 ix 2002, Sarder Nasir Uddin N-1643 (DACB).

8. Drymoglossum piloselloides C. Presl, Tent. Pterid. 227, p. 10, f. 5, 6 (1836). Pyrrosia piloselloides (L.) Price (1974). Creeping, epiphytic herb. Commonly occurs in both Sitapahar and Rampahar areas on tree trunks. Representative specimens: Rangamati dist.: Sitapahar, Kaptai, 23 ix 2002, Sarder Nasir Uddin N-1489 (DACB); Rampahar, Kaptai, 30 v 2003, Sarder Nasir Uddin N-1981 (DACB). 
9. Drynaria quercifolia (L.) J. Sm. in Hook. J. Bot. 3: 398 (1841). Short creeping, epiphytic herb. Frequently occurs in both Sitapahar and Rampahar areas on varieties of tree species. Representative specimens: Rangamati dist.: Sitapahar, Kaptai, 23 ix 2002, Sarder Nasir Uddin N-1481 (DACB); Rampahar, Kaptai, 30 v 2003, Sarder Nasir Uddin N1962 (DACB).

10. Microsorum pteropus (Blume) Copel., Univ. Calif. Publ. Bot. 16: 112 (1929). Rhizomatous, epiphytic herb. Commonly occurs in Rampahar area on shady and wet rocks along the streams. Representative specimen: Rangamati dist.: Rampahar, Kaptai, 16 vi 2001, Sarder Nasir Uddin N-1009 (DACB).

11. Microsorum punctatum (L.) Copel., Univ. Calif. Publ. Bot. 16: 111 (1929). Rhizomatous, epiphytic herb. Commonly occurs in Sitapahar area on tree trunks and mossy rocks. Representative specimen: Rangamati dist.: Sitapahar, Kaptai, 23 ix 2002, Sarder Nasir Uddin N-1491 (DACB).

12. Pyrrosia lanceolatum (L.) Farw., Amer. Midl. Nat. 12: 245 (1931). Creeping rhizomatous, epiphytic herb. Commonly occurs in Rampahar area on tree trunks and moist rocks. Representative specimen: Rangamati dist.: Rampahar, Kaptai, 03 x 2002, Sarder Nasir Uddin N-1818 (DACB).

SCHIZAEACEAE Kaulf. (1824).

13. Lygodium flexuosum (L.) Sw. in Schrad. J. Bot. 1800 (2): 106 (1801). Rhizomatous, climbing herb. Frequently occurs in both Sitapahar and Rampahar areas in shady forest cover. Representative specimens: Rangamati dist.: Sitapahar, Kaptai, 24 ix 2002, Sarder Nasir Uddin N-1525 (DACB); Rampahar, Kaptai, 30 ix 2002, Sarder Nasir Uddin N1645 (DACB).

PTERIDACEAE Ching (1982).

14. Adiantum philippense L., Sp. Pl. 2: 1094 (1753). Tufted herb. Commonly occurs in both Sitapahar and Rampahar areas on hill slopes or on crevices of rocks or walls. Representative specimens: Rangamati dist.: Sitapahar, Kaptai, 24 ix 2002, Sarder Nasir Uddin N-1547 (DACB); Rampahar, Kaptai, 03 x 2002, Sarder Nasir Uddin N-1805 (DACB).

15. Ceratopteris thalictroides (L.) Brongn. in Bull. Sci. Soc. Philom. Paris ser. 3, 8: 186 (1821). Aquatic, free floating or attached herb. Rarely occurs in Sitapahar area in marshy places near river bank. Representative specimen: Rangamati dist.: Sitapahar, 02 v 2008, Sarder Nasir Uddin N-2932 (DACB).

16. Cheilanthes grisea Blanford, J. Simla Nat. Hist. Soc. 1: 21 (1886). Rhizomatous, tufted fern. Rarely occurs in Sitapahar area in open rocky areas. Representative specimen: Rangamati dist.: Sitapahar, Kaptai, 25 ix 2002, Sarder Nasir Uddin N-1569 (DACB).

17. Doryopteris ludens (Wall. ex Hook.) J. Sm., Hist. Fil.: 189 (1875). Long creeping, rhizomatous herb. Occasionally occurs in Rampahar area in shady forest beds. 
Representative specimen: Rangamati dist.: Rampahar, Kaptai, 30 ix 2002, Sarder Nasir Uddin N-1626 (DACB).

18. Onychium siliculosum (Desv.) C. Chr, Ind. Fil. 20: 468 (1906). Onychium auratum Kaulf. (1824). Rhizomatous herb. Less frequently occurs in both Sitapahar and Rampahar areas in shady forest beds. Representative specimens: Rangamati dist.: Sitapahar, Kaptai, 19 xii 2004, Sarder Nasir Uddin N-2646 (DACB); Rampahar, Kaptai, 07 i 2005, Sarder Nasir Uddin N-2701 (DACB).

19. Pityrogramma calomelanos (L.) Link, Handb. Erken. Gew. 3: 20 (1833). Rhizomatous, tufted herb. Occasionally occurs in Rampahar area in shady forest beds. Representative specimen: Rangamati dist.: Rampahar, Kaptai, 07 i 2005, Sarder Nasir Uddin N-2702 (DACB).

20. Pteris ensiformis Burm. f., Fl. Ind.: 230 (1768). Rhizomatous herb. Frequently occurs in both Sitapahar and Rampahar areas in shady forest beds. Representative specimens: Rangamati dist.: Sitapahar, Kaptai, 23 ix 2002, Sarder Nasir Uddin N-1484 (DACB); Rampahar, Kaptai, 03 × 2002, Sarder Nasir Uddin N-1808 (DACB).

21. Pteris geminata Wall. apud Hook., Spect. Fil. 1: 53 (1846). Rhizomatous, tufted herb. Rarely occurs in Sitapahar area in shady forest beds. Representative specimen: Rangamati dist.: Sitapahar, Kaptai, 18 xii 2004, Sarder Nasir Uddin N-2609 (DACB).

22. Pteris griffithii Hook., Sp. Fil. 2: 170, t. 123 A (1853). Rhizomatous herb. Rarely occurs in Sitapahar area in shady hill slopes. Representative specimen: Rangamati dist.: Sitapahar, Kaptai, 19 xii 2004, Sarder Nasir Uddin N-2647 (DACB).

23. Pteris pellucida Presl, Rel. Haenk. 1: 55 (1825). Rhizomatous herb. Frequently occurs in Rampahar area in shady, bushy forests. Representative specimen: Rangamati dist.: Rampahar, Kaptai, 30 ix 2002, Sarder Nasir Uddin N-1671 (DACB).

24. Pteris venusta Kunze in Bot. Zeit. 6: 195 (1868). Rhizomatous herb. Rarely occurs in Sitapahar area in hill slopes. Representative specimen: Rangamati dist.: Sitapahar, Kaptai, 24 ix 2002, Sarder Nasir Uddin N-1527 (DACB).

VITTARIACEAE (Presl) Ching (1940).

25. Vittaria elongata Sw., Syn. Fil. 109, 302 (1806). Rhizomatous, tufted, epiphytic herb. Occasionally occurs in Rampahar area on tree trunks. Representative specimen: Rangamati dist.: Rampahar, Kaptai, 19 x 2003, Sarder Nasir Uddin N-2181 (DACB).

DENNSTAEDTIACEAE Pichi Sermolli (1970).

26. Microlepia speluncae (L.) Moore, Ind. Fil.: 93 (1857). Creeping, rhizomatous herb. Commonly occurs in Sitapahar area in dry hill slopes and margins of forests. Representative specimen: Rangamati dist.: Sitapahar, Kaptai, 17 vi 2001, Sarder Nasir Uddin N-1051 (DACB). 
THELYPTERIDACEAE Ching (1970).

27. Thelypteris arida (D. Don) Morton, Amer. Fern J. 49: 113 (1959). Christella arida (D. Don) Holtt. (1974). Long-creeping, rhizomatous herb. Frequently occurs in Sitapahar area in grassy fields and waysides to hills. Representative specimen: Rangamati dist.: Sitapahar, Kaptai, 22 ix 2002, Sarder Nasir Uddin N-1440 (DACB).

28. Thelypteris crinipes (Hook.) K. Iwats., J. Jap. Bot. 38: 315 (1963). Christella crinipes (Hook.) Holtt. (1974). Rhizomatous herb. Less frequently occurs in Sitapahar area along streams. Representative specimen: Rangamati dist.: Sitapahar, Kaptai, 24 ix 2002, Sarder Nasir Uddin N-1523 (DACB).

29. Thelypteris cylindrothrix (Rosenst.) K. Iwats. in Hara, Fl. E. Himal.: 482 (1966). Christella cylindrothrix (Rosenst.) Holtt. (1974). Long-creeping, rhizomatous herb. Rarely occurs in Sitapahar area in shady forest beds. Representative specimen: Rangamati dist.: Sitapahar, Kaptai, 18 xii 2004, Sarder Nasir Uddin N-2602 (DACB).

30. Thelypteris nudata (Roxb.) Morton, Contr. U. S. Nat. Herb. 38: 352 (1974). Pronephrium nudatum (Roxb. ex Griff.) Holtt. (1972). Creeping, rhizomatous herb. Frequently occurs in Rampahar area in shady forest beds near springs. Representative specimen: Rangamati dist.: Rampahar, Kaptai, 30 ix 2002, Sarder Nasir Uddin N-1704 (DACB).

31. Trigonospora calcarata (Blume) Holttum, Reinwardia 8: 506 (1974). Nephrodium calcaratum Hook. (1862). Rhizomatous, tufted herb. Very rarely occurs in Sitapahar area on wet rocks near springs. Representative specimen: Rangamati dist.: Sitapahar, Kaptai, 17 vi 2001, Sarder Nasir Uddin N-1064 (DACB).

ASPLENIACEAE Frank (1877).

32. Asplenium nidus L., Sp. Pl. 2: 1079 (1753). Rhizomatous, epiphytic herb. Frequently occurs in Rampahar area on tree trunks or shady rocks. Representative specimen: Rangamati dist.: Rampahar, Kaptai, 16 x 2003, Sarder Nasir Uddin N-2035 (DACB).

33. Asplenium unilaterale Lamk., Encycl. 3: 305 (1786). Rhizomatous herb. Frequently occurs in Rampahar area on shady and wet rocks. Representative specimen: Rangamati dist.: Rampahar, Kaptai, 16 x 2003, Sarder Nasir Uddin N-2050 (DACB).

DRYOPTERIDACEAE Ching (1941).

34. Diplazium esculentum (Retz.) Sw., Schrad. J. Bot. 1801 (2): 312 (1803). Rhizomatous, tufted herb. Frequently occurs in Rampahar area in shady and moist places. Representative specimen: Rangamati dist.: Rampahar, Kaptai, 15 xii 2004, Sarder Nasir Uddin N-2531 (DACB).

35. Diplazium polypodioides Blume, Enum. Pl. Jav.: 194 (1828). Long-creeping, rhizomatous herb. Frequently occurs in Rampahar area on hill slopes, at forest edges. 
Representative specimen: Rangamati dist.: Rampahar, Kaptai, 30 ix 2002, Sarder Nasir Uddin N-1674 (DACB).

36. Diplazium spectabile (Wall. ex Mett.) Ching in Lingnam Sci. J. 15: 278 (1936). Creeping, rhizomatous herb. Occasionally occurs in Sitapahar area in shady forest beds. Representative specimen: Rangamati dist.: Sitapahar, Kaptai, 06 i 2005, Sarder Nasir Uddin N-2684 (DACB).

37. Pleocnemia irregularis (Presl) Holttum, Kew Bull. 29: 347 (1974). Tectaria irregularis (Presl) Copel (1929). Rhizomatous herb. Less frequently occurs in Rampahar area in shady, hill slopes of dense forests. Representative specimen: Rangamati dist.: Rampahar, Kaptai, 16 x 2003, Sarder Nasir Uddin N-2077 (DACB).

38. Tectaria chattagramica (Clarke) Ching, Sinensia 2 (2): 35 (1931). Rhizomatous herb. Rarely occurs in Rampahar area in lowlands and shady hill slopes, in evergreen forests. Representative specimen: Rangamati dist.: Rampahar, Kaptai, 02 x 2002, Sarder Nasir Uddin N-1759 (DACB).

39. Tectaria heterosora (Bak.) Ching, Sinensia 2 (2): 35 (1931). Creeping, rhizomatous herb. Commonly occurs in both Rampahar and Sitapahar areas along the springs, in hilly evergreen forests. Representative specimens: Rangamati dist.: Sitapahar, Kaptai, 22 ix 2002, Sarder Nasir N-1417 (DACB); Rampahar, Kaptai, 30 ix 2002, Sarder Nasir Uddin N-1673 (DACB).

40. Tectaria paradox (Fee) Sledge, Kew Bull. 27 (3): 413 (1972). Rhizomatous, tufted herb. Rarely occurs in Sitapahar area along the streams, in hilly evergreen forests. Representative specimen: Rangamati dist.: Sitapahar, Kaptai, 20 xii 2004, Sarder Nasir Uddin N-2651 (DACB).

LOMARIOPSIDACEAE Aloton (1956).

41. Bolbitis hookeriana K. Iwats., Acta Phytotax. Geobot. 18: 49 (1959). Bolbilis appendiculata (Willd.) K. Iwats. (1959) subsp. vivipara (Hook.) Hennipman (1970). Rhizomatous herb. Less frequently occurs in Sitapahar area in evergreen and semievergreen forests. Representative specimen: Rangamati dist.: Sitapahar, Kaptai, 22 ix 2002, Sarder Nasir uddin N-1420 (DACB).

Floristic study of Rampahar and Sitapahar reserve forests has recorded a total 41 pteridophyte species distributed in 26 genera and 13 families. Of which, one species is aquatic, eight species are epiphytic and 32 species are terrestrial. Analysis shows that four families viz. Pteridaceae (11 species), Dryopteridaceae (7 species), Polypodiaceae (6 species) and Thelypteridaceae (5 species) constitute more than 70 per cent of total fern flora of the area, whereas, remaining nine families constitute less than 30 per cent. The study has found that 17 species are confined to Rampahar area, 14 species are confined to Sitapahar and only 10 species occur in both Rampahar and Sitapahar areas. This indicates 
that fern species are very much specific to their substrates or habitats. Among those species, Tectaria chattagramica (Clarke) Ching has been enlisted in Red data book by Khan et al.(20) The analysis also found that the study area (only 966 hactres of land) harbours 21 per cent of total fern flora of the country. Hence, it can be concluded that the area is an important habitat for fern species in the country.

\section{Acknowledgements}

Author's special thanks to the authority of the Bangladesh Forest Department for their co-operation during the field works. They are grateful to the authorities of the following herbaria for allowing to consult their libraries and use their herbarium materials viz. Bangladesh National Herbarium (DACB), Dhaka University Salar Khan Herbarium and Bangladesh Forest Research Institute Herbarium, Chittagong (BFRI).

\section{References}

1. Anonymous 1960. Working Plan of the Chittagong Hill Tracts North and South Forest Division for the period from 1953-54 to 1972-73, vol. 2. Working Plan Division, Forest Department, the Government of East Pakistan.

2. Prain D 1903 (Indian reprint 1981). Bengal Plants, vol. 2. Bishen Singh Mahendra Pal Singh, Dehra Dun, India. pp. 663-1319.

3. Pasha MK and AU Mallik 1980. Ferns of Bangladesh-I. Chittagong Univ. Stud. Pt. II. (Sci.) 2(4): 13-26.

4. Pasha MK and R Chakraborty 1984. Ferns of Bangladesh-III. The genus Adiantum. Chittagong Univ. Stud. Pt. II. (Sci.) 8(2): 113-121.

5. Pasha MK 1985. A systematic account of Selaginella from Bangladesh. Bangladesh J. Bot. 14(2): 97107.

6. Mirza MM and MM Rahman 1997. An annotated checklist of ferns and fern-allies of Bangladesh. Bangladesh J. Plant Taxon. 4 (2): 47-69.

7. Uddin MG and MK Pasha 1997. Systematic studies on the fern-allies of Bangladesh. Indian Fern J. 14: 23-32.

8. Uddin MG. 2001. A taxonomic study on Leptosporangiate ferns of Bangladesh. M. Phil. Thesis, Department of Botany, University of Chittagong. pp. 1-239.

9. Siddiqui KU, MA Islam, ZU Ahmed, ZNT Begum, MA Hassan, M Khondker, MM Rahman, SMH Kabir, M Ahmed, ATA Ahmed, AKT Rahman and \& EU Haque (eds.) 2007. Encyclopedia of Flora and Fauna of Bangladesh, vol.-5, pp. 1-391. Asiatic Society of Bangladesh, Dhaka.

10. Uddin MG and MK Pasha 2002. Wetland Pteridophytic flora of Bangladesh. The Chittagong University J. Sci. 26(1 \& 2): 93-104.

11. Uddin MG and MK Pasha 2007. Diversity \& distribution of epiphytic pteridophytes in Bangladesh. J. Taxon. Biodiv. Res. 2: 59-65.

12. Beddome RH 1883 (Indian reprint 1976). A Handbook to the Ferns of British India, Ceylon and Malaya Peninsula. pp. 1-300. New Delhi, India. 
13. Clarke CB 1880 (Indian reprint 1973). A Review of the Ferns of Northern India. Trans. Linn. Soc. London-II. Bot. 1: 425-611.

14. Holttum RE 1968. A Revised Flora of Malaya. Fern of Malaya 2. Singapore Govt. Printing Office, Singapore. pp. 1-653.

15. Holttum RE. 1991. Flora Malesiana. Pteridophyta. Fern and Fern allies. ser. 2, vol. 2, part 1. Foundation Flora Malesiana. pp. 1-132.

16. Dixit RD 1984. A Census of the Indian Pteridophytes. pp. 1-177. Bot. Surv. India. Dept. Env.

17. Smitinand $\mathrm{T}$ and K Larsen (eds) 1975. Flora of Thailand, vol. 2, part 3, pp. 1-280. Applied Scientific Research Corporation of Thailand, Bangkok.

18. Smitinand $\mathrm{T}$ and $\mathrm{K}$ Larsen (eds) 1989. Flora of Thailand, vol. 3, part 4, pp. 1-640.. Forest Herbarium, Royal Forest Department, Bangkok.

19. Tagawa M and K Iwatsuki 1972. Families and Genera of the Pteridophytes known from Thailand. Mem. Fac. Sci. Kyoto Univ. Biol. Sci. 67-88.

20. Khan MS, MM Rahman and MA Ali (eds) 2001. Red Data Book of Vascular Plants of Bangladesh. Bangladesh National Herbarium, Dhaka, Bangladesh. pp. 1-179.

(Manuscript received on 13 September, 2011; revised on 13 June, 2012) 
